\title{
Die Grundbedeutung der hebräischen Wurzel רד.
}

\author{
Von A. Büchler in London.
}

Die nur in den Propheten und in dichterischen Stellen der Bibel vorkommende Wurzel קדר bedeutet nach GESENIUS-BUHL I. schmutzig sein, wie in der Sprache der Mišna und des Targums und wie, تخب im Arabischen ${ }^{\mathrm{x}}$; 2. in schmutzigen Kleidern umhergehen, trauern; 3. sich schwärzen, vom Tage, von Sonne und Mond. Hierüber besteht, soweit ich sehe, weder bei den Bibelauslegern, noch bei den Semitisten eine erhebliche Meinungsverschiedenheit. $\mathrm{Um}$ so bemerkenswerter ist es, dals im palästinischen Hebräisch und Aramäisch des zweiten und dritten Jahrhunderts die Wurzel קד in grade entgegengesetzter Bedeutung sich findet, was in keinem der talmudischen Wörterbücher auch nur vermerkt, geschweige erklärt wird. Es handelt sich aber nicht etwa, wie man aus der völligen Nichtbeachtung der eigentümlichen Erscheinung schließen könnte, um eine vereinzelte, unsichere Stelle, sondern um mehrere, wẻnn auch nicht gleichwertige Belege aus dem talmudischen Schriftum.

I. In b. 'Abodâ zarâ $2^{a} 3^{a}$ schildert R. Hanina b. Papa, nach anderer Überlieferung R. Simlai (um 280-320, bzw. 250-300) in längerer Ausfuhrung, die im Talmud durch verschiedenartige Bemerkungen anderer Lehrer, gleichsam durch Glossen, unterbrochen wird, wie Gott in der . messianischen Zeit die heidnischen Völker wegen ihrer Nichtbeachtung der Thora zur Rede stellen wird, wie sich die Heiden damit rechtfertigen werden, daß sie die Thora nicht offenbart bekamen, und wie sie sich nun bereit erklären, dieselbe von jetzt ab zu beobachten; wie Gott sie hierauf, um sie auf die Probe zu stellen, zur Beobachtung des leichten Gebotes über das Wohnen in der Laubhütte auffordert, und hierauf alle auf den Dächern Laubhütten bauen, Gott aber, um ihre Standhaftigkeit zu erproben, מקדיר עליהם חמה כבתקופת תמוז וכל אחד ואחד מבעם בסוכתו ה'וי die Sonne auf sie, wie zur Z.eit der Sonnenwende des Monats Tammûz קדר läßt, so $\mathrm{da}$ jeder seine Laubhütte stehen läßt und weggeht." $\mathrm{Da}$ von großer Hitze die Rede ist, zeigt schon der Hinweis auf die Sonnenwende des Tammûz, wann die Hitze in Palästina, unerträglich

I ZDMG 40, 729; LAGARDE, Übers. 31, vergleicht auch رứ trübe sein.

2 Vgl. Bachẹr, Agada der pal. Amoräer I, 566. 
wirdz, so dab רד, wie allgemein übersetzt wird, die Glut der Sonne bezeichnet; und מקדיר wäre zu übersetzen: er läßt strahlen oder glühen. Aber woher diese Bedeutung der Wurzel? RAŠI, der in seinem Kommentar zum Talmud die überlieferte Erklärung darstellt, bemerkt ${ }^{2}$ : die Sonne durchlöchert mit der Kraft der großen Hitze, wie dasselbe Wort in 'Erub. 58a : man durchbohrt (beim Messen einer Entfernung gleichsam) die Berge. (= man mißt die Luftlınie); das Wort bedeutet durchlöchern, schneiden ${ }^{3}$. Diese Wurzel findet sich in der Tat öfter ${ }^{4}$; aber die Parallele bei RAŠI könnte bedenklich scheinen, weil die Cambridger Mišna,

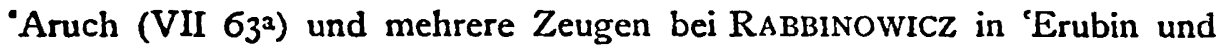
anderwärts קדר lesen5, wăhrend meines Wissens für מקדיר an der uns

I In Tanhuma B. הisn 6, Tanḥuma 8 sagt R. Jehuda b. R. Ilai (siche Bubers Note über den Urheber des Satzes): Die Sonne befindet sich in einer Hülle und um die Sonnenwende des Tammúz kommt sie aus der Hülle heraus, um die Früchte zu reifen, und die Welt kann sie nicht ertragen. Exod. rab. 15,6: Wer kann um die Sonnenwende des Tammûz vor der Sonne bestehen, alles flieht vor ihr; vgl. noch Midrá ₹ 196 ; und $b_{0}$ Sabb, 53 a. Daß große Hitze im Herbste am Laubhüttenfeste vorkam, erhellt aus der Baraitha in jer. Sukká II $53 \mathrm{~b} 23$ : so wie man die Laubhütte wegen Regens verlassen darf, so darf man es auch wegen der Sonnenglut (ברו) und der Mūcken tun.

2 מנקבת בכח תום נדול כמו טקדרין בהרים דעירובין ענין נקב חות

3 Das zu ergānzende Objekt könnte die Luft sein, vgl. b. Joma 20b, Genes. ráb. 6, 7: R. Levi sagt: Der Sonnenball durchsägt bei Tag die Luft, wie ein Zimmermann Zedern. Für die Vorstellung, daß das Sonnenlicht eine Mauer durchbohrend gedacht wurde, könnte auf Jes $58_{8}$ (siehe weiter S. 63) und auf jer. Berakb. I $2 \mathrm{C} 40$ hingewiesen werden, wo wahrscheiulich in Anlehnung an diese Bibelstelle erzāhlt wird: R. Hijija und R. Simon b. Hạalaftha הוו מהלכין בהדא בקעת ארבל בקריצתה וראו אילת השתר שבקע אורה gingen am frūhen Morgen in der Ebene von Arbel und sahen, wie das Licht der Mörgenröte spaltend hervorbrach. Das Gleiche findet sich vom Feuer der Hōlle im Satze des R. Jannai in Genes. rab. 48, 8 zu Genes. 18 I והרתיח כל העולם כולו על יושביו לטעה קלד und deren Feụer machte die Welt in kurzer Zeit den Menschen heiß. Ähnliches vom Monde in jer. Roš hašaña II 58 a 51 : R. Hạinâ ging nach 'Ên-Tab, um den Neumondstag zu bestimmen, aber der Hımmel war umwölkt und der Mond nicht sichthar, als R. Haninâ darob unmutig ward, והקדיח לו הקדוש ברוך הוא ככברה.ונראה מתוכה machte Gott Löcher in die Wolken, dab sie wie ein Sieb aussahen, und der Mond wurde sichtbar. Vgl. auch בק rom Hervorbrechen der Morgenröte in der Meša'-Inschrift Zeile 15.

4 Zum Beispiel sagt $R$. Josê in der Baraitha in Sabb. 116a: Aus den Büchern der Hāretiker בחול קותר את האוכרוות סבואן schneide man, wenn man sie an einem Wochentage findet, die Gottesnamen aus und verbrenne dann die Bücher. Ebenso in Synhedr. 103 b, Abodâ 22râ 32a, Hullin 50b, 77 a und sonst.

5 סופרים 2u 'Erub. 58 a p. 232, Levy, Neuhebr. WB IV 244b; ABulwalid hat gleichfalls so gelesen, s. BAchER, Leben und Werke des Abulwalid 84, 6, Agada der pal Amoräer III $2 \delta$ zum Satze des R. Zeira in jer. Berakh. I $2^{e}{ }_{36}$. R. Salomo b. haJathôn, ed. Chᄉjes p. 122 zu Moẽd Kat. 26 a bemerkt zu polgendes:

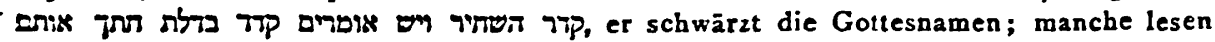
Tip, es bedeutet: er schneidet sie aus. Oppenhen in Berliners Magazin II 20 ver- 
beschaftigenden Stelle keine Variante verzeichnet ist. Ferner ist

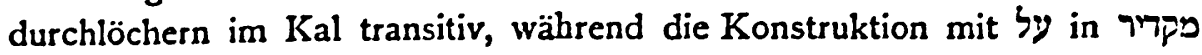
dafür zu sprechen scheint, da@ das Kal hier intransitiv ist.

2. Gegen die Identifizierung der beiden Wurzeln spricht die Parallelstelle des angefuhrten Ausspruches von R. Simon b. Lakis, die das fragliche קדר gleichfalls enthält ${ }^{2}$ : In der künftigen Welt wird es keine Hölle geben, sondern Gott wird die Sonne aus ihrer Hülle herausnehmen inpist und sie gluhen lassen; die Bösen werden durch sie gestraft, die Frommen dagegen geheilt werden, nach Ma 3 19 20. Da מקדירה erst steht, nachdem die Sonne die Hulle verloren hat, kann es nicht durchlöchern bedeuten, sondern nur glühen oder ähnliches. Unmittelbar vorher heift es als Erklärung einer Vergleichung von Menschen mit Fischen in Hab I $^{3}$ : Sowie die Fische des Meeres, sobald die Sonne auf sie scheint (iרוק), sterben, ebenso die Menschen. Dieselbe Bedeutung hat pip auch in der

weist auf das samaritanische קרד als Übersetzung von pand liest mit Aruch Tip in H.ullin 50b und Synh. 103b. Zur Baraitha in Beṣâ $29 a$ unten verzeichnet Rabbinowicz keine Variante, die Parallelstelle in Tó. Jôm Tób III $\delta$ hat dafür חוק.

I Freilich könnte trotz על ein zweites Objekt ergänzt werden und 2 war die Hülle, die nach jüdischer Auffassurg die Sonne umgibt, wie R. Hamz zu Genes. $18 x$ in Baba meși a 86b sagt: Es war der dritte Tag nach der Beschneidung Abrahams, als Gott diesen besuchte und die Sonne aus ihrer Hülle (נרת (j) nahm, damit keine Reisenden den Frommen behelligen. Dafür spräche auch die Rolle, die der Sonne in der messianischen Zeit zugedacht wird in Genes. rab. 6, 6: Der Sonnenball hat eine Hülle nach Psalm I9 5 und ein Wasserteich liegt vor ihm; wenn die Sonne aufgehen soll, schwãcht Gott vorher ihre Kraft im Teiche ab (vgl. Midraš Psalm 196), damit sie die Welt nicht verbrenne. Aber in der künftigen Welt wird Gott die Sonne ihrer Hülle entkleiden und durch die. Sonne die.Frevier verbrennen, nach Maleachi $3 \mathrm{sg}_{9}$. Ebenso sagt R. Simon b. Lakiš oder Jannai in Nedar. 8b (BAcher, Pal. Amoräer I 44, 5). Der Satz wāre hiernach zu übersetzen: Gott ließ die Sonne ihre Hül!e über den Heiden durchbohren, damit die Glut die Heiden treffe.

2 Abodâ zarâ 3b unten; die Parallele in Nedar. 8b lautet genau so, aber fehlt; es ist wohl kaum zweifelhaft, daß der vollere und schwierigere Text trotz der Nachbarschaft von פקיר auf p. 3 a ursprünglich ist. RABBINowicz verzeichnet keine Variante dazu.

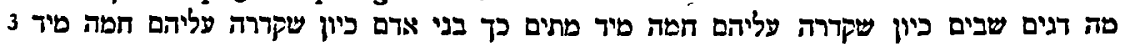
טתים. Daß nicht etwa nach Joël 2 Io $_{0}$ I5 24 übersetzen ist: sobald die Sonne sich verfinstert, erhellt schon aus dem ganzen Zusammenhange, der die vernichtende Wirkung der Sonnenglut vorführt; abgeseken davon, wird nirgends von der tödlichen Wirkung der Sonnenfinsternis gesprochen, sondern nur von ihrer schlechten Vorbedeutung. Es

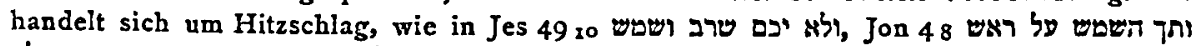

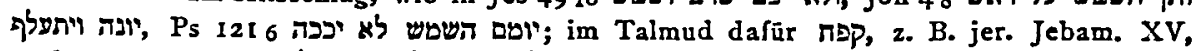

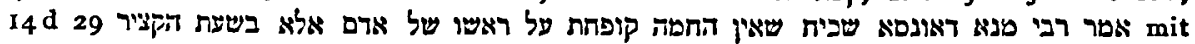

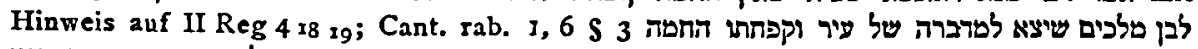
על ראשו ונתכרכמו פניו, siehe jetzt IM. Löw, Lexikalische Miszellen, in Zeitschrift f. Assyrio.

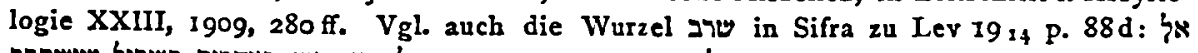
תאמר לו ציא בהשבמה שיקפחוהו ליסטים צא בצוהרים בשביל שישתרב 
aramäischen Agada in Pesah. $118^{b}$. Als der Feldherr Sisera (Jdc 4 5) gegen die Israeliten zog, kan er über sie mit eisernen 'דקר; da ließ Gott die Sterne aus ihren Bahnen gegen die Heiden treten (Judic 520 ). Als die Sterne nièderstiegen, machten sie die eisernen (אקדירו), so $\mathrm{da}$ die Feinde gezwungen waren, im Kišon Abkühlung zu suchen ${ }^{\mathrm{x}}$. Natürlich ist unter den Sternen wegen der Hitze die Sonne allein gemeint, wie in allen angefuhrten Stellen mit קד; die Sterne sind nur aus Rücksicht auf das gedeutete Bibelwort genannt. Die Bedeutung gluhen fur קדר scheint aber gesichert.

Schlieblich sei noch auf die weniger sichere Baraitha in Ta'anith $20^{2}$ hingewiesen. Der fromme und reiche Nakdimon b. Gorjon in Jerusalem hatte sich in einem Jahre der Dürre von einem römischen Herrn mehrere Zisternen Wasser fur die Wallfahrer ausgeliehen, und sollte das Wasser an einem bestimmten Tage entweder in natura zuruickerstatten oder mit Geld teuer bezahlen. Als Gott auf sein Gebet im letzten Augenblicke des festgesetzten Tages regnen lieb, sagte der Hegemon, die Sonne wäre bereits untergegangen, der Abend schon eingetreten und der Termin abgelaufen. Da betete Nakdinıon nochmals zu Gott und die Wolken zerstreuten sich und die Sonne strahlte wieder. Hierauf sprach der Hegemon: Hätte die Sonne nicht geschienen (נקדרה), hätte ich das Recht gehabt, mein Geld von dir zu fordern ${ }^{2}$. Auch hier erklärt RAŠI wie zu der allerersten Stelle, daß die Sonne den Himmel durchschnitt und strahlte3. Er ergänzt den Luftraum, weil er nur die Bedeutung durchbohren für diesen Zusammenhang kannte und der Sinn ein synonymes Wort für strahlen erforderte. Das Wort נקדרה selbst ist durch die von den Kommentatoren herangezogene Parallele aus 'Erubin gesichert, wo sie

I Das Wọrt אקרירו worde weder von den Abschreibern, noch von den Kommentatoren des Talmud meb̀r erkannt. Jalkut (II 53) läbt, wie oft in schnierigen Stellen, den aus vier Worten bestehenden Satz einfach im ganzen weg. Die Münchener Handschrift hat: ונחיתו כוכבי פלייהו אתו דאקרי und RABBisowicz zur Stelle bemerkt zu der unverständlichen Leseart, - es müsse vielleicht Kommentator nach dem Sinne tatsächlich rekonstruiert הגך רכבי דפרולא אתחמימו

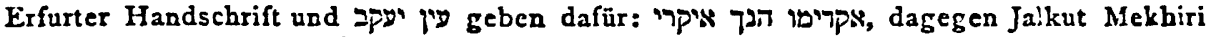
zu Psalm 117 p. 208 כיון דקרח עלטג עלייהו, was nach der Lesart in einer Handschrift bei ביון שקרח עלמא עלייהו אמרי ניתות ניקור נפשין : als die Welt über ihnen glühend geworden war, sprachen sie: Wir wollen absteigen und uns abkūhlen. Aber die unverstāndlichen Varianten אתדקארי ,קדח, führen alle auf das von den Ausgaben dargebotene das schwierige קדר.

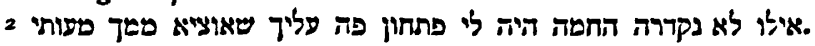

טקרר בהרים Toßafôth bemerken

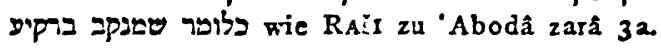


und nicht TTp gelesen haben, es wäre denn, dab sie hier und dort TTP hatten ${ }^{3}$, was nicht wahrscheinlich ist. gleichbedeutend, mul jedoch nicht blolj strahlen, sondern heif bestrahlen bedeutet haben ${ }^{2}$.

3. Ist dieses klar, so ist es sehr auffallend, daf dieselbe Wurzel in Jo 2 to die Verfinsterung der Sonne und des Mondes bezeichnet. Allerdings liegt es nahe, einfach zwei Wurzeln mit verschiedener Aussprache des zweiten Wurzelbuchstaben anzunehmen, indem قذر das biblische ר. فد bedeutet. Ist es aber an sich schwer denkbar, dalj das aus der Bibel wohltekannte Wort für Verfinsterung, das auch in der Sprache der palästinischen Lehrer furtlebte', auch für das Strahlen der Sonne sollte gebraucht worden sein, so ist es ebenso fraglich, ob die Annahme einer zweiten Wurzel überhaupt begründet ist. Gegen dieselbe spricht die Wahrnehmung, dals mehrere semitische Wurzeln, die Hitze bedeuten, auch

1 Die Münchener Talmudhandschrift hat für das den Abschreibern unverständliche Tipa das gelāufigere, im Bericht selbst frūher vorkommende הm gesetzt, eine zweite Handschrift hat, wie Gittin 56a, 17 נ, ebenso עין und andere. Unterstūtzt wird die letz-

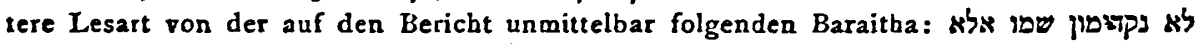
er hieb nicht Nakdimon, sondern Boni, er warde auch Nakdimon genannt, weil die Sonne ihm zu Liebe wieder geschienen hat. Da im Namen der Buchstabe 7 nicht vorkommt, muß das Zeitwort ing und nicht gelautet haben. LevY (Neuhebr. WB III 433b) liest in der Tat הips und gibt dem Stamme נק die Bedeutung glänzen, klar sein, ohne aber hierfür einen Beleg anfübren zu können. Ebenso Kohut ( 377 a), der die bei RabBinowicz zusammengestellten Zeugen mitteilt; so JASTROW s. v. נק: break through. In Wabrheit aber ist die $\mathrm{Ba}=$ raitha mit der Deutung des Namens Nakdimon offenbar jūnger, als der Bericht vom Wunder; sie beruht auf der Wahrnehmung, dab eine Stelle die Begebenheit von Nakdimon, eine andere von einem sonst unbekannten Boni erzāhlte, und eine Kombınierung beider erzielt werden solle. So ist die dritte Baraitha, die Moses, Josua und Nakdimon dasselbe Wunder des Wiedererstrablens der Sonne zuschreibt, eine noch jüngere $Z u$ sammenstellung, שלשה נקדמה להם המה בעבורן. Die Münchener Handschrift hat auch hier

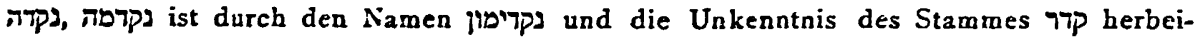
geführt worden, legt es aber nahe, daß zwischen 7 und $\boldsymbol{n}$ noch ein Buchstabe stand und zwar ein 7 , wie die bisher besprochenen Stellen mit ריק, zu denen keine Variante הTק verzeichnet wird, lehren.

2 Wie הרתית in Synb. rogb בן יצדר בן שהרתיח עליו את העולם כצהרים, beinahe wört-

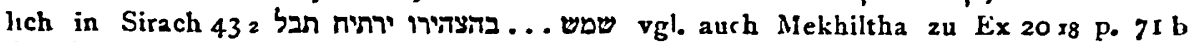
מתמה • freilich Jalkut statt wo רבי יהודה ברבי אילפהי אומר לפי שהתיו משולהבין מחמה של מעלן

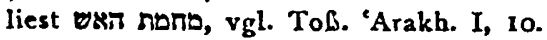

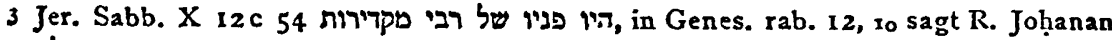
רושעים קומתן כפופה ופניהם טקדירות לעתז לבוג, in beiden Stellen von der.Verfinsterung des

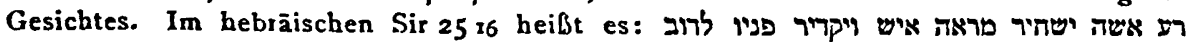
vgl. Ferles in Revue des Etudes Juives XXXV, 1897, 60, Ginzberg in Nöldekes Orient. Studien 623. 
schwarz und düster heißen, genau wie קדר in den obigen Ausführungen'; und der Zusammenhang zwischen beiden Bedeutungen wird durch die Vergleichung des sich verfinsternden Gesichtes mit dem rußigen Boden des Topfes im Talmud ${ }^{2}$ angedeutet. Brand und Schwärze liegen einander sehr nahe. حَّ = hebräisch, aramäisch und syrisch heiß sein, wàrmen, aber auch schwarz sein, II. Form $=$ mit Kohle schwär-

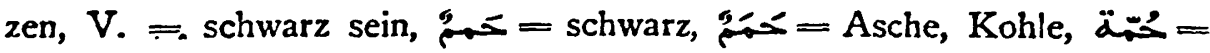
colör inter nigredinem et ruborem infra colorem viridem in nigrum vergentem (FREYTAG), ebenso andere Nominalformen desselben Stammes. ا calidus fuit, II ferve fecit, XII nigra fuit res ut nox et nubes. Beide Wurzeln haben offenbar erst die Hitze des Feuers bezeichnet, die alles schwärzt und zu Kohle verbrennt3. سفع سَفْع " leviter adussit, color niger cum rubro, سَفْع niger. nigrique quid in fundo reliquit. ش شssit aliquem eiusque colorem mutavit, cinereo colore praeditus fuit4. Im Hebräischen bedeutet כטר schwärzen, dunkel machen, traurig sein, und der Syrer übersetzt 387 durch בכטירותא, ebenso Ps 42 10 432 Jer 821 Ez 3115 Job 30285. Dagegen kann נכמרו רחטיו in Gen 4330 keine der angefuhrten Bedeutungen haben, ebensowenig עורנו כתנור נכמרו in Thr 5 10, wenn auch mit GESENIUS-BUHL angenommen würde: „,in Gährung gebracht werden, oder: unsere Haut ist rissig, runzelig geworden, von dem tönernen Ofen, der durch die glühende Hitze berstet; weniger treffend die gewöhnliche Übersetzung: geschwärzt werden. Im Neuhebraisch-talmudischen: durch Hineinlegen in die Erde oder auf andere Weise eine künstliche Reife der Früchte oder ihre Gährung hervorrufen"6. Es bedeutet ohne Zweifel erhitzen, heib werden.

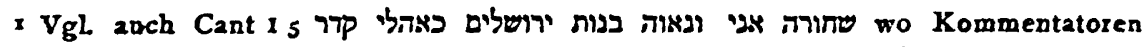
in 7 eine Anspielung auf schwarz sehen; das Arabische hat dafür, wie schon erwāhnt, تخر und كدر.

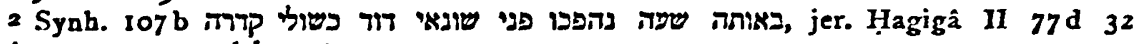

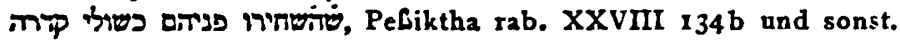

3 תר bedeutet in den semitischen Sprachen glühen, im Soqotri nach D. H. MüLLER in ZDMG LVIII 1904, 781 schwarz. Vgl. auch wحصم nigredo mit wiخم calefecit,

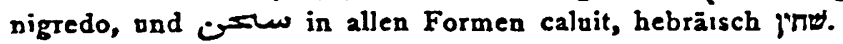

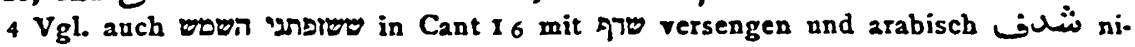
sredo noctis tumquoque aurcra ciusque adventus, IV. Form accendit lucernam.

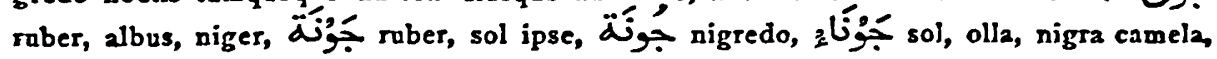
تَّ, IX, VIII $x$.

5 Siehe die Zusammenstellung bei Paynz-Surrh s. $v$.

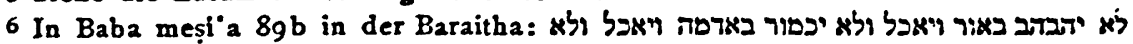

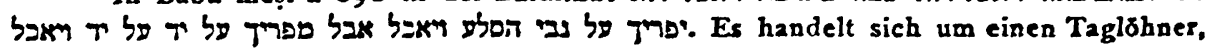


Mit קמר ist verwandt, denn Targum gibt במדר שמרז in Ps 35 14, das der Syrer durch בעמירות שמר שתיית wibeder, ebenso in $\mathrm{P}_{\mathrm{S}} 3_{7}{ }_{7}$ חמר הלכית. Es folgt hieraus mit hoher Wahrscheinlichkeit, daß תמר schwarz, schmutzig oder àhnliches bedeutet ${ }^{x}$. Andererseits übersetzt

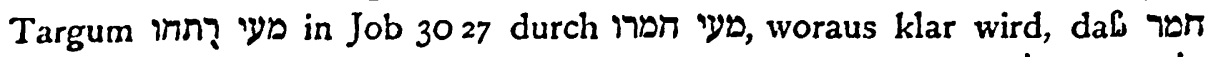
heif sein bedeutet, ebenso wie im Targum zu Ps 140 II כגיצין דמחמרין schwarze oder ausgebrannte Kohlen². So auch in Mišna Synhedr. VII 2: bei der Hinrichtung durch Feuer zündet man eine Schnur an (? = schmilzt Blei), wirft sie dem Verurteilten in den gewaltsam geöffneten Mund, die Schnur dringt in sein Inneres und verbrennt seine Eingeweide3. Und in Mišna Hullin III 3: wenn ein Vogel ins Feuer fällt und seine Eingeweide verbrannt (נחמרו) werden, so ist er, wenn diese gelb sind, zum Genusse unbrauchbar, wenn rot, brauchbar ${ }^{4}$. Hierher gehört auch der Stamm שחם שחן ind ersterer ist im Targum zu Job שתימיו 6 שקודרים die Übersetzung vond heißt im Syrischen schwarz, im Talmud schwärzlich, von der Sonne gèbrannt, arabisch schwarz sein'; שח bedeutet in der Bibel Entzündung und die Wurzel kommt in der Mišna und im Syrischen als Verb vor, im Ara-

der sich von den Früchten, die er für seinen Arbeitgeber sammelt, ninmt und sìch die Frucht schmackhafter macht, hierdurch aber auf Kosten des Herrn mehr ibt. Da kann natürlich keine, längere Zeit beanspruchende Behandlung der Frucht gemeint sein, sondern, wie das Absengen und Zerreiben der Ähren, eine, die den baldigen Genuß ermöglicht; כמר müßte das Einlegen für kurze Zeit, höchstens einige Stunden bedeuten (Máasr. IV, I). In Baba meși'a 74 a bezeichnet כמר das Erhitzen von Oliven und

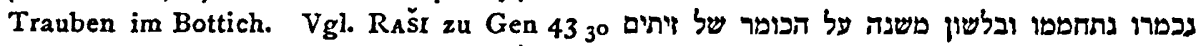
נכמרו derch erhitzen ibersetzt, wie in der Mišna and im talmudischen Aramäisch.

$x$ LAGarde, Hagiographa chaldaice hat in beiden Psalmenstellen weder aus dem hebräisch-aramäischen חכר irgendwie erkJärt werden kann. Es ist offenbar nur Verschreibung für חמר.

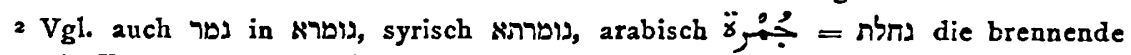

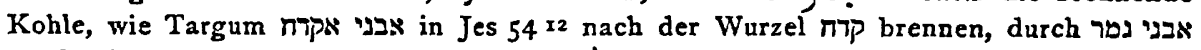

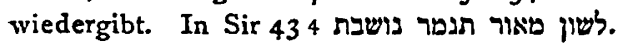

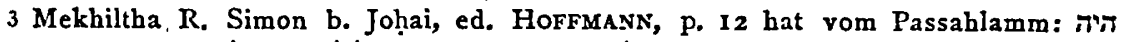

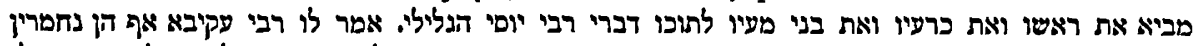

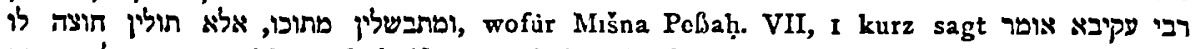

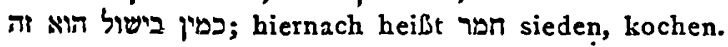

4 Der Gaon von Pumbeditha, R. Hai führt zur Erklärung der Wurzel nמר Dan

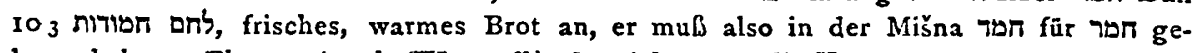
lesen haben. Ebenso Aruch (III $424 \mathrm{ff}$ ), der sich gegen die Kommentatoren, R. Geršom, R. Hananel und Raši (ebenso Maimuni) für חמד entscheidet, wiewohl er selbst die Lesart תמר mit dem Hinweis auf Thr 2 Ix 2 als vorhanden anerkennt. Auch die Cambridger Mišna hat itinis.

5 Onkelos gibt in Gen 303233 חום durch wieder. 
bischen bedeutet س س diesen Beispielen, die für ein und dieselbe Wurzel die Bedeutung von Hitze und Schwärze erweisen, klar, daß auch phne Differenzierung im zweiten Wurzelbuchstaben Glut und Schwärze bedeuten konnte ${ }^{2}$. Es fragt sich aber, ob dieses auf eine Beobachtung des menschlichen Feuers, das selbst heiß ist und den Topf schwärzt, zurückgeht, oder, wie es die Verwendung von קדר Talmud ausschließlich von der Glut der Sonne nahelegt, auf die Wirkung der Sonne. Da ferner das biblische קדר in erster Reihe die Verfinsterung der Sonne, des Mondes und des Himmels bezeichnet, wären wir geneigt, die Grundbedeutung dieser Wurzel und aller behandelten von der Beobachtung der Sonne abzuleiten, deren zwei Wirkungen in einem Stamme ausgedrückt worden wären. Andererseits weisen die besprochenen arabischen Wörter für Hitze und Schwärze auf das gewöhnliche Feuer hin, wie auch das Wort für Topf קדרה 3, wenn wir auch die Vorstellung finden, dab die Sonne ein Feuertopf oder ein glühender Stein ist 4.

4. Für die Sonne spricht folgende Wahrnehmung an einigen Stämmen, die Hitze bedeuten. Wir haben gefunden, daß רTp, falls die Lesung sicher ist, nicht bloß glühen und schwärzen, sondern auch schneiden bedeutet. Das Gleiche lehrt $\pi$ Th, das in den semitischen Sprachen brennen heibt, in seiner zweiten, in der Mišna öfter vorkommenden Bedeutung aber durchbohren, durchlöchern, besonders מקדר Bohrer. Ebenso heibt חרר allgemein glühen, aber auch durchlöchern, wozu schon LEVY (Neuhebr. WB II II6b) bemerkt: „vielleicht ursprünglich ausbrennen (Ohalôth XIII, I, III 7)", תריר - Nadelöhr in Kelim XIII. 5, ebenso im Syrischen (vgl. תור Loch). Diese Bedeutung geht wahrscheinlich entweder auf die Beobachtung zurück, dab das Feuer nicht nur hei $\$$ und schwarz macht, sondern auch ein Loch in Gegenstände brennt, oder auf die Wahrnehmung, daf die Sonne durch die engste Spalte dringt. Dieses erinnert zunächst an יבקע כשחר זורך in Jes 588 (oben S. 57, Note 3), wo vom Lichte gesagt wird, dab es durch Spalten hervorbricht, wie die

I Siehe Schulthess, Homonyme Wurzeln im Syrischen, s. v. שח p. 75 und dazu Nölderz in ZDMG 54, 1900, 157; oben Seite 61, Note 3.

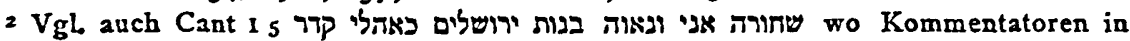
קדine Anspielung auf pin schwarz sehen; das Arabische hat dafür, wie schon erwāhnt,

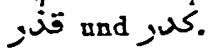

3 Uber arabisch قدر siehe Fraenkel, Aram. Fremdwörter 63, G. JAcoв, Altarab. Beduinenleben 93 .

4 Siehe besonders Hans Schmid Jona 59 a und passim, Archiv f. Religionswissenschaft $1906,179$. 
Morgenröte. Hierfür ist der Stamm شَرت besonders lehrreich, denn er bedeutet: fidit, dissecavit rem, ut aurem ovi, ebenso in der Form شَرتق dann ortus fuit sol, ferner eine Farbe: habuit flavescentes dactylos palma, rubuit in oculo sanguis, und schlieblich, was auf die Anschauung des durch die Spalte dringenden Lichtes klar hinweist, شَرَّق trans per fissuram. Im Assyrischen heibt sarku rotes Blut, sabäisch שרק De Sie Sonne geht auf, wie im Arabischen Ebenso heibt

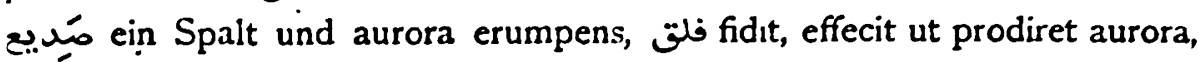
فَلق fissura in monte, aurora eiuvse lux erumpens, فصل فئ apparuit aurora, rubescentes seu flavescentes dactylos habuit palma, im Hebräischen פצכ öffnen, klar und heiter sein, verschiedenfarbig sein, schminken, ثقب perforavit, accensus fuit arsitque ignis et luxit fulsitque stella vel ignis, valde rubuit, ebenso in abgeleiteten Formen ${ }^{2}$. Hiernach wäre קדר schneiden nicht auf die Beobachtung der Wirkung des Feuers, sondern auf die der Sonne zurückzuführen. Doch möchte ich zum Schlusse bemerkèn, daß manche Erwägung, die hier auszuführen zu weitläufig wäre, für das menschliche Feuer, den glühend gemachten Stein und die Wirkung beider

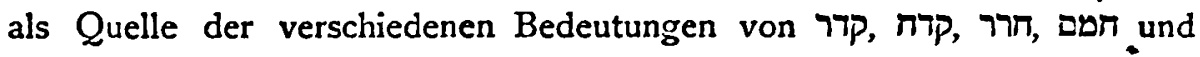
anderer hier behandelter Stämme spricht ${ }^{3}$.

I Das hebräische השריק in Sir 439507 wurde als Arabismus angesehen, wird aber von NöLDEKE in ZAW XX 1900, 85 f. als gut hebräisch erklārt, d2 שרק = spalten, durchbrechen, von der Sonne = aufgehen, auch in anderen semitischen Dialekten vorkommt. Schon bei Ephräm Syrus findet sich als gut syrisches Wort קשר im Sinne ron strahlend glānzen; siehe RysSel in Theolog. Studien u. Kritiken 1902, $413,3$.

2 Als Beispiel scheinbar verschiedenartigster und miteinander nicht zusammen:" hangender Bedeutungen sei der Stamm فقع angeführt. Nach FreYtaG: valde flavus furt vel habuit colorem flavum purum, non mixtum alio, pulcher, purus fuit, adolevit puer, (تقع ruber fuit), II rubro colore tinxit, VI albus fuit, dazu Nomina verschiedener Formen. Eine hiervon völlig verschiedene, dem hebräischen פק = platzen entsprechende Bedeutung von فتع ist fregit, mortuus fuit calore, crepitum ventris emisit, II junctos digitos celeriter dimovit et sic crepitum excitavit, V contracta fuit manus, VII fissus fuit, dazu weitere Nomina, $\ddot{\alpha} \ddot{\alpha}^{\circ}{ }^{\circ}$ avis niger radicem caudae albam habens. IV miser, pauper fuit, gehört zur ersten Form, insofern die fahle Gesichtsfarbe auf den Zustand

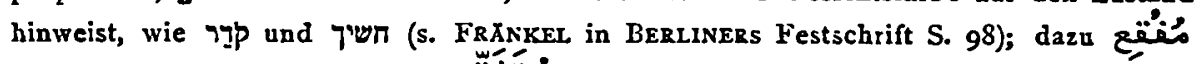
deprimens hominem paupertas, مُنَفَنِّع durus, quum aridus fit, de planta, ist die Be-

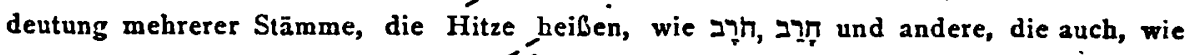
dieses durchbohren bedeuten, vgl. خَرَّك.

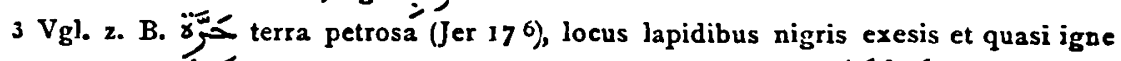

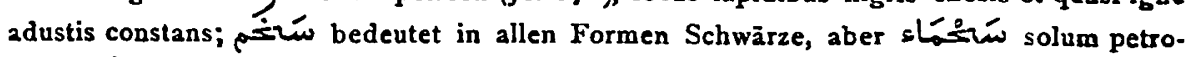
sum, cuius pars aspera est. 